\title{
Pneumoconiosis in different sectors and their differences in Turkey
}

\author{
Nur Şafak ALICI ${ }^{1}$ \\ Arif ÇIMRIN ${ }^{1}$ \\ Ayşe COŞKUN BEYAN ${ }^{2}$
}

\footnotetext{
${ }^{1}$ Department of Chest Diseases, Faculty of Medicine, Dokuz Eylul University, Izmir, Turkey

${ }^{1}$ Dokuz Eylül Üniverstesi Tıp Fakültesi, Göğüs Hastalıkları Anabilim Dalı, Izmir, Türkiye

${ }^{2}$ Clinic of Chest Diseases, Izmir Dr. Suat Seren Chest Diseases and Chest Surgery Training and Research Hospital, Izmir, Turkey

2 izmir Dr. Suat Seren Göğüs Hastalıkları ve Cerrahisi Eğitim ve Araştırma Hastanesi, Gögüs Hastalıkları Kliniği, İzmir, Turkey
}

\section{SUMMARY}

\section{Pneumoconiosis in different sectors and their differences in Turkey}

Introduction: Pneumoconiosis which is one of the ancient diseases, still affects many workers throughout the world despite "existing" control programs. We add data from a single center reviewing risk factors for pneumoconiosis; evaluate functional and radiological findings in different sectors.

Patients and Methods: We reviewed medical records of patients diagnosed with pneumoconiosis who were admitted to our center between the years 2013 and 2015. Several personal and occupational features, together with functional and radiologic data, were collected.

Results: 60 were young males. Twenty-four of the cases (39.3\%) worked at dental technician, 24 cases (39.3\%) were ceramic workers, 5 cases $(8.2 \%)$ were sandblasters, 2 cases (3.3\%) were welders, 3 cases (4.9\%) were miners, and 3 cases (4.9\%) were marble cutters. The sectors in which the exposure started at the earliest ages were dental technicians and sandblasters, while the shortest working time was in sandblasting. The dental technicians were younger than the ceramic workers at the age of diagnosis (Kruskall-Wallis $p=0.003$ ). The exposure time of the sandblasters was significantly shorter, especially than the ceramic workers (Kruskall-Wallis $p=0.002$ ). The cases have been referred to us with pneumoconiosis suspicion based on the radiographic findings in the PA chest roentgenogram performed during the periodic examinations at their work place; but unlike other studies, in our study, following the HRCT assessment, cases which did not present any visible pathology in the re-evaluation of their PA chest roentgenogram, but had HRCT findings have been diagnosed as pneumoconiosis. Among the 44 cases in which micro-nodules had been detected at their HRCT, 15 of them had been previously classified as profusion of small opacities 0/1 according to their PA chest roentgenogram findings. It has been seen that the HRCT findings differ among sectors. Ceramics workers and sandblasters had significantly more micro-nodules, while dental technicians had significantly more mediastinal lymphadenopathies (Chi square, $p=0.004$ and $p=0.007$ respectively). When the relationship between the existence of big opacities and complaints was studied, statistically significant weight loss was detected in cases which had C opacities (chi square $p=0.01$ ). Statistically significant FEV decrease was observed in cases which had weight loss (independent samples t-test $p=0.046$ ). It has been observed that when the profusion of small opacities increased, while there was no statistically significant functional status change in non-smokers, a significant functional impairment was observed in smokers.

\section{Yazışma Adresi (Address for Correspondence)}

Dr. Nur Şafak ALICI

Dokuz Eylül Üniverstesi Tıp Fakültesi,

Gögüs Hastalıkları Anabilim Dalı, IZMiR - TURKEY

e-mail: safak.alici@hotmail.com 
Conclusion: Pneumoconiosis still exists in Turkey. Even a short exposure time as 2 years can cause pneumoconiosis. Workers in different sectors had different functional, radiological properties and smoking can affect the diseases' course. There are serious limitations related to the surveillance of both the workplace environment and the employees' health in Turkey. Without institutional preventive measures, personal protection and surveillance examinations, occupational hazards will continue to cause premature deaths. Pneumoconiosis in different sectors is a prototype of uncontrolled industry in the developing world.

Key words: Pneumoconiosis, different sectors, radiological findings

\section{ÖZET}

\section{Türkiye'de sektörlere göre pnömokonyoz ve farklı özellikleri}

Giriş: Pnömokonyoz, tamamen önlenebilir bir hastalık olmasına rağmen, günümüzde halen en sık görülen meslek hastalığıdır. Türkiye'de pnömokonyozun günümüzdeki durumuna ışık tutması amacı ile son 2 yıl içerisinde kliniğimize müracaat ederek pnömokonyoz tanısı koyduğumuz olgular, kişisel, sektörel, tıbbi ve sosyoekonomik yönleri ile sunuldu.

Hastalar ve Metod: Merkezimize 2013-2015 yılları arasında başvuran ve pnömokonyoz tanısı alan 61 olgunun bilgileri retrospektif olarak değerlendirildi. Kişisel, mesleksel özellikleri radyolojik ve fonksiyonel durumları ile birlikte değerlendirildi.

Bulgular: Olguların 60'ı erkekti ve bunlardan; 24 (\%39.3) olgu seramik, 24 (\%39.3) olgu diş protez yapımı, 5 (\%8.2) olgu kumlamacı, 2 (\%3.3) olgu kaynakçı, 3 (\% 4.9) olgu maden işçisi, 3 (\%4.9) olgu mermer kesimcisi idi. Maruziyetin en erken başladığı iş kolları diş protez işçiliği ve kumlamacılık iken, en kısa çalışma süresine sahip iş kumlamacılık idi. Tanı sırasında diş teknisyenleri seramik işçilerine göre daha genç idi (Kruskall-Wallis $p=0.003$ ). Kumlamacıların maruziyet süresi özellikle seramik işçilerine göre anlamlı olarak daha kısaydı (Kruskall-Wallis $p=0.002$ ). Diğer çalışmalardan farklı olarak çalışmamızda, yüksek çözünürlüklü bilgisayarlı tomografi bulguları bulunup PA akciğer grafisinde patolojik görünüm saptanmayan olgular pnömokonyoz tanısı aldı. Yüksek çözünürlüklü bilgisiyarlı tomografide mikronodül saptanan 44 olgunun 15'i PA akciğer grafisinde küçük opasite profüzyonu 0/1 olarak değerlendirilmişti.

Sonuç: Türkiye'de pnömokonyoz varlığını sürdürmektedir. Iki yıl gibi kısa süreli bir maruziyet pnömokonyoza yol açabilmektedir. Farklı sektörlerdeki çalışanlarda farklı fonksiyonel, radyolojik özellikler ve sigara içme durumu hastalı̆̆ın seyrine etkilidir. Bu durum işyeri ortamı ve çalışan sağ/ığı izlemi ile ilişkili ciddi kısıtıılıkların olduğunu göstermektedir.

Anahtar kelimeler: Pnömokonyoz, farklı sektörler, radyolojik bulgular

\section{INTRODUCTION}

The International Labour Office (ILO) defines pneumoconiosis as dust accumulation at the lungs due to occupational and environmental factors, and the tissue reaction resulting from this dust accumulation (1). Even though pneumoconiosis is a totally preventable disease, it is currently still the most frequently seen occupational disease $(1,2)$. According to a study which the World Health Organisation (WHO) has conducted, there are 30.000 deaths and 1.288.000 disability adjusted life years (DALY) due to pneumoconiosis (2). Up till 40 years ago, in many countries around the world, disease prevalence among employees working at sectors with pneumoconiosis risk was reported as 30\% (3). Owing to the importance given to the dust control measures in the last years, there has been a serious decrease in the pneumoconiosis prevalence around the world (4). However \%80 of the employees in developing countries are working at small scale enterprises under unhealthy and dangerous conditions, and also without any health insurance, therefore various epidemics occur (4). Sufficient statistical data related to occupational diseases cannot be found in Turkey (5).
Nevertheless, from the many studies conducted regarding pneumoconiosis, it can be seen that many sectors such as textile, metal, mining, dental prosthesis and ceramics carry a severe risk of pneumoconiosis (6-10). One of the researches reports that more than 200,000 employees in Turkey work at sectors which have pneumoconiosis risk (11).

In order to enlighten the current situation of pneumoconiosis in Turkey, the cases which have applied to out outpatient clinic in the last two years and diagnosed as pneumoconiosis have been presented in this study in relation with their personal, sectoral, medical and socio-economical aspects.

\section{MATERIALS and METHODS}

This study is a cross-sectional study. A total of 450 cases had applied to the Dokuz Eylül University Hospital Occupational Diseases Outpatient Clinic between the years 2013 and 2015. Following their examination 61 of them had been diagnosed with pneumoconiosis. These cases' patient files have been evaluated retrospectively. The retrospective evaluation has been conducted by a standard Chest Physician and Occupational Diseases specialist. 
An anamnesis including a detailed work history had been taken from, and a physical examination had been performed to each case during their application. Their posteroanterior (PA) chest roentgenogram had been obtained. High Resolution Computerized Lung Tomography (HRCT) had been obtained from the cases who had been referred to our outpatient clinic with pneumoconiosis suspicion based upon the PA chest roentgenogram obtained during their periodical workplace examination which had been evaluated as having $1 / 0$ profusion. All the PA chest roentgenogram have been evaluated according to the ILO 2000 classification. According to this classification, the ones which had small opacities with a profusion of more than 1/0 have been accepted as pneumoconiosis (1).

During the HRCT evaluation, solitary nodules or a nodule which was a couple of millimetres and inside a restricted area have not been considered as pneumoconiosis. These cases have been suggested to be followed-up. If existed, their prior PA chest roentgenogram, thorax CT's and HRCT's have also been evaluated. In the HRCT's, opacities which were surrounded with lung parenchyma and were relatively rounded have been defined as 'micronodule' if their diameter was $3 \mathrm{~mm}$ or smaller, and as 'nodule' if their diameter was between $3 \mathrm{~mm}$ and $3 \mathrm{~cm}$; while a homogeneous and diffuse increase in the lung parenchyma density has been defined as 'consolidation' (12). According to the ILO classification, the ones with profusion $0 / 1,1 / 0,1 / 1$ and $1 / 2$ have been classified as category 1 ; the ones with profusion 2/1,2/2 and 2/3 have been classified as category 2 ; and the ones with profusion $3 / 2,3 / 3$ and $3 /+$ have been classified as category 3 .

Following the clinical evaluation, the Social Security Institution, the audit units of the Ministry of Labour and Social Security, and the Ministry of Health Public Health Agency of Turkey have been informed about the cases and the workplaces.

The spirometric assessments have been conducted with a SensorMedics Vmax22 0.6-2B vers. spirometer device, in accordance with the American Thoracic Society (ATS) criteria (13). The spirometric data of the cases have been evaluated according to the percentage of the expected values.

The statistical evaluations have been conducted by computer, using the PASW Statistics for Windows (SPSS Inc. Version 18.0, Released 2009, Chicago, USA) package statistical program. The mean, median, minimum-maximum and standard deviation of the data have been calculated. The differences between the age of diagnosis, the age of starting work, and the exposure time among various sectors have been evaluated with the Kruskall-Wallis test. The HRCT findings in relation with the sectors have been compared with the Chi Square test. The relationship between the PA chest roentgenogram findings and the cases' complaints has been compared with the Chi Square test. The relationship between the functional status evaluation, and the findings and complaints has been evaluated with the independent samples t-test. The functional status of the cases in according to the existence of radiological findings among smokers and non-smokers has been analysed with the One-way ANOVA test. The distribution of the radiological patterns according to the shape and profusion has been assessed with the Pearson correlation test. The age of diagnosis, the age of starting work, the total time of employment and the exposure time according to the sectors have been compared with the Kruskall-Wallis test. The Benforonicorrected Mann-Whitney $U$ test was performed in order to assess which groups were causing the difference. $p<0.05$ has been accepted as significant.

\section{RESULTS}

Among the 61 cases which constitute the study group, 60 were young males. Twenty-four of the cases $(39.3 \%)$ worked at dental technician, 24 cases $(39.3 \%)$ were ceramic workers, 5 cases $(8.2 \%)$ were sandblasters, 2 cases $(3.3 \%)$ were welders, 3 cases $(4.9 \%)$ were miners, and 3 cases $(4.9 \%)$ were marble cutters. It was seen that the cases had started working at early ages and that their exposure time varied from 2 to 30 years. The socio-demographic and work related properties of the cases have been presented in Table 1. The sectors in which the exposure started at the earliest ages were dental technicians and sandblasters, while the shortest working time was in sandblasting. Sandblasting was performed in several sectors such as rifle barrel, dental prosthesis, glass, jeans production and at metal stoning (14). One of the cases with pneumoconiosis was a female who had performed duties such as emptying, weighing, and mixing dust chemical materials in a firm which produced dental materials.

Significant differences have been detected between the age of diagnosis, age of starting work, exposure time and sectors. The dental technicians were younger 
Table 1. The socio-demographic and work related properties of the cases

\begin{tabular}{|c|c|}
\hline Properties & $n=61$ \\
\hline $\operatorname{Sex}(F=M)$ & 60.1 \\
\hline Age (year)* & $38.1 \pm 6.8(22-54)$ \\
\hline $\begin{array}{l}\text { Number of patients have } \\
\text { smoking history } \mathrm{n}(\%)\end{array}$ & $50(82 \%)$ \\
\hline Smoking history ${ }^{\#}$ & $15 \pm 7(5-35)$ \\
\hline Age of starting work* & $21.38 \pm 5.9(11-41)$ \\
\hline Age at diagnosis* & $38.10 \pm 6.8(22-54)$ \\
\hline Exposure time $^{+}$ & $147.03 \pm 82.3(24-305)$ \\
\hline Total working time $^{+}$ & $164.50 \pm 79.8(24-384)$ \\
\hline
\end{tabular}

than the ceramic workers at the age of diagnosis (Kruskall-Wallis $p=0.003$ ). The exposure time of the sandblasters was significantly shorter, especially than the ceramic workers (Kruskall-Wallis $p=0.002$ ) (Table 2).

The cases' spirometric data which was calculated according to the percentage of the expected values, and also the mean, minimum and maximum values have been found as $\mathrm{FEV}_{1} 83.67 \pm 18.20 \%$ (26-113), FVC $87.8 \pm 15.7 \%$ (35-114), FEV $_{1} /$ FVC $77.6 \pm 7.9 \%$ (48-87) and PEF $87.3 \pm 22.0 \%$ (34-128).
Following the PA chest roentgenogram evaluation, the distribution of the radiological patterns according to their shape and profusion have been shown in Figure 1, and the distribution of the profusion of small opacities according to the sectors have been shown in Table 3. The cases have been referred to us with pneumoconiosis suspicion based on the radiographic findings in the PA chest roentgenogram performed during the periodic examinations at their work place; but unlike other studies, in our study, following the HRCT assessment, cases which did not present any visible pathology in the re-evaluation of their PA chest roentgenogram, but had HRCT findings have been diagnosed as pneumoconiosis.

When the HRCT findings of the 61 cases were examined, it was seen that 44 case $(72.1 \%)$ had micronodules, 26 cases (42.6\%) had lymphadenopathy, 21 cases $(34.4 \%)$ had nodules, 17 cases $(27.9 \%)$ had reticular opacities, 3 cases $(21.3 \%)$ had consolidation, 7 cases $(11.5 \%)$ had conglomerate masses, 3 cases $(4.9 \%)$ had calcification, 3 cases $(4.9 \%)$ had ground glass opacity, and 3 cases $(4.9 \%)$ had traction bronchiectasis. Among the 44 cases in which micronodules had been detected at their HRCT, 15 of them had been previously classified as profusion of small opacities 0/1 according to their PA chest roentgenogram findings. The distribution of the profusion of small opacities, according to the sectors

Table 2. The properties of the cases with pneumoconiosis, according to the sectors

\begin{tabular}{|c|c|c|c|c|}
\hline Sector & $\begin{array}{l}\text { Age at diagnosis } \\
\text { (year)* }\end{array}$ & $\begin{array}{l}\text { Age of starting } \\
\text { work (year)* }\end{array}$ & $\begin{array}{l}\text { Total working } \\
\text { time (month)* }\end{array}$ & $\begin{array}{l}\text { Exposure time } \\
\text { (month)* }\end{array}$ \\
\hline Ceramic workers $(n=24)$ & $\begin{array}{l}41.33 \pm 1.19 \\
42.00(27-54)^{\#}\end{array}$ & $\begin{array}{l}23.96 \pm 0.97 \\
23.0(16-41)^{\#}\end{array}$ & $\begin{array}{l}191.71 \pm 16.61 \\
204.0(24-305)^{\#}\end{array}$ & $\begin{array}{l}194.21 \pm 17.25 \\
210.0(24-305)^{\#}\end{array}$ \\
\hline Dental technicians $(n=24)$ & $\begin{array}{l}34.29 \pm 1.29 \\
34.0(22-44)^{\#}\end{array}$ & $\begin{array}{l}17.46 \pm 0.97 \\
16.0(11-30)^{\#}\end{array}$ & $\begin{array}{l}159.50 \pm 15.67 \\
146.0(24-384)\end{array}$ & $\begin{array}{l}125.0 \pm 12.57 \\
120.0(24-264)^{\#}\end{array}$ \\
\hline Sand blasters $(n=5)$ & $\begin{array}{l}36.6 \pm 2.56 \\
37.0(29-43)\end{array}$ & $\begin{array}{l}23.0 \pm 2.47 \\
26.0(17-28)\end{array}$ & $\begin{array}{l}87.40 \pm 19.00 \\
90.0(24-131)^{\#}\end{array}$ & $\begin{array}{l}48.0 \pm 8.48 \\
48.0(24-72) \#\end{array}$ \\
\hline Welders $(n=2)$ & $\begin{array}{l}41.50 \pm 5.5 \\
41.5(36-47)\end{array}$ & $\begin{array}{l}32.50 \pm 2.5 \\
32.5(30-35)^{\#}\end{array}$ & $\begin{array}{l}104.0 \pm 20.0 \\
104.0(84-124)\end{array}$ & $\begin{array}{l}96.0 \pm 12.0 \\
96.0(84-108)\end{array}$ \\
\hline Miners $(n=3)$ & $\begin{array}{l}43.67 \pm 4.91 \\
47.0(34-50)\end{array}$ & $\begin{array}{l}25.0 \pm 3.6 \\
27.0(18-30)\end{array}$ & $\begin{array}{l}128.0 \pm 59.73 \\
108.0(36-240)\end{array}$ & $\begin{array}{l}124.0 \pm 62.86 \\
108.0(24-240)\end{array}$ \\
\hline Marblecutters $(\mathrm{n}=3)$ & $\begin{array}{l}37.67 \pm 2.60 \\
38.0(33-42)\end{array}$ & $\begin{array}{l}18.33 \pm 1.85 \\
17.0(16-22)\end{array}$ & $\begin{array}{l}192.67 \pm 24.82 \\
192.0(150-236)\end{array}$ & $\begin{array}{l}168.0 \pm 36.66 \\
144(120-240)\end{array}$ \\
\hline$P$ & $\begin{array}{l}0.005 \\
\text { \#Only difference in } \\
\text { ceramic and dental } \\
\text { technician had been } \\
\text { significant }\end{array}$ & $\begin{array}{l}<0.001 \\
\text { \#Only difference in } \\
\text { ceramic and dental } \\
\text { technician had been } \\
\text { significant }\end{array}$ & $\begin{array}{l}0.077 \\
\text { \#ceramic and sand } \\
\text { blasters-marblecutters } \\
\text { and sand blasters } \\
\text { difference had been } \\
\text { significant }\end{array}$ & $\begin{array}{l}0.001 \\
\text { \#ceramic workers had } \\
\text { longer exposure time } \\
\text { than dental technicians } \\
\text { but sandblasters had } \\
\text { significantly shorter } \\
\text { exposure time }\end{array}$ \\
\hline
\end{tabular}


Alıcı NŞ, Çımrın A, Coşkun Beyan A.

Table 3. The distribution of the profusion of small opacities according to the sectors

\begin{tabular}{|c|c|c|c|c|c|c|c|c|c|c|c|c|}
\hline \multirow[b]{3}{*}{ Sectors } & \multicolumn{3}{|c|}{$\mathbf{p}$} & \multicolumn{3}{|c|}{$q$} & \multicolumn{3}{|c|}{$\mathbf{r}$} & \multicolumn{3}{|c|}{ s } \\
\hline & 1 & 2 & 3 & 1 & 2 & 3 & 1 & 2 & 3 & 1 & 2 & 3 \\
\hline & n (\%) & n (\%) & n (\%) & n (\%) & n (\%) & n (\%) & n (\%) & n (\%) & n (\%) & n (\%) & n (\%) & n (\%) \\
\hline Ceramic workers & $17(70.8 \%)$ & & & $2(8.3 \%)$ & $2(8.3 \%)$ & $1(4.3 \%)$ & & & & $2(8.3 \%)$ & & \\
\hline Dental technicians & $8(33.3 \%)$ & $1(4.2 \%)$ & & $1(4.2 \%)$ & $5(20.8)$ & $5(20.8)$ & & $2(8.3 \%)$ & $2(8.3 \%)$ & & & \\
\hline Sandblasters & $4(80 \%)$ & & & & & & & & $1(20 \%)$ & & & \\
\hline Welders & $2(100 \%)$ & & & & & & & & & & & \\
\hline Miners & $3(100 \%)$ & & & & & & & & & & & \\
\hline Marblecutters & $1(33.3 \%)$ & $1(33.3 \%)$ & & & & & & & $1(33.3 \%)$ & & & \\
\hline
\end{tabular}

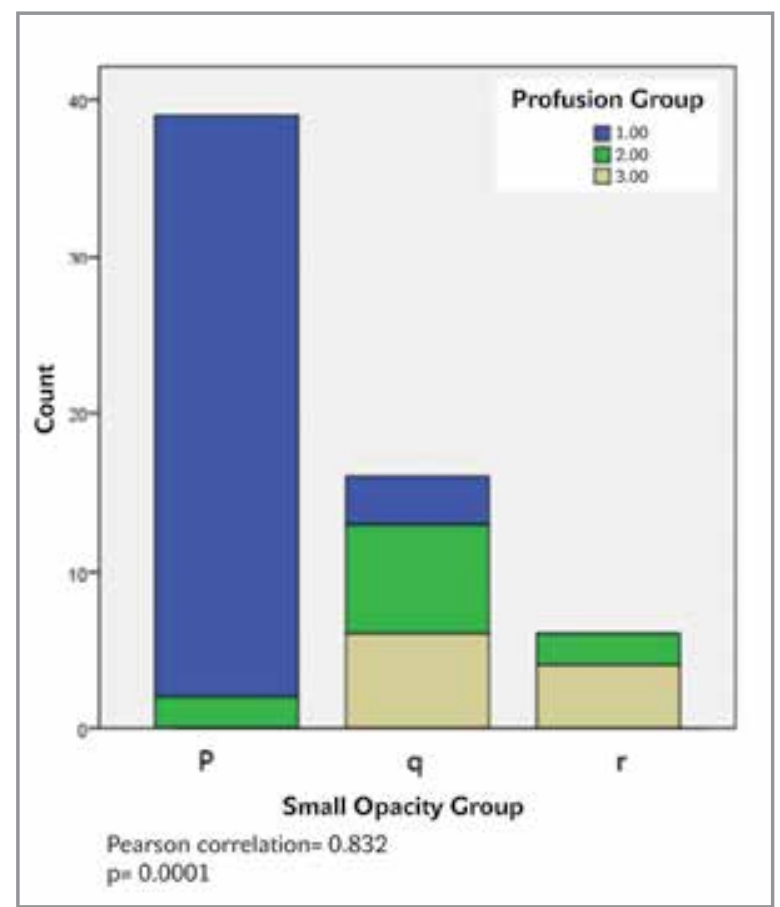

Figure 1. The distribution of the radiological patterns according to their shape and profusion.

has been provided in Table 3. It has been seen that the HRCT findings differ among sectors. Ceramics workers and sandblasters had significantly more micro-nodules, while dental technicians had significantly more mediastinal lymphadenopathies (Chi Square, $p=0.004$ and $p=0.007$ respectively).

It was statistically significant that the cases became symptomatic with the increase of size in the radiologic big opacities (Chi Square $p=0.008$ ). When the relationship between the existence of big opacities and complaints was studied, statistically significant weight loss was detected in cases which had C opacities (Chi Square $p=0.01$ ). Statistically significant
$\mathrm{FEV}_{1}$ decrease was observed in cases which had weight loss (independent samples t- test $\mathrm{p}=0.046$ ).

In cases who smoked, a significant relationship has not been observed between the existence of small opacities and the cases' functional status. However it has been observed that when the profusion of small opacities increased, while there was no statistically significant functional status change in non-smokers, a significant functional impairment was observed in smokers (Table 4). While there has not been found any difference between the functional statuses of no-smokers with big opacities, the functional impairment detected in smokers with big opacities was statistically significant (Table 5).

\section{DISCUSSION}

It can be seen that females as well as males are under the risk of pneumoconiosis in Turkey. The sector in which we have diagnosed pneumoconiosis the most is the ceramic sector which is a labour intensive field. The second most pneumoconiosis diagnosis is from the dental prosthesis field in which the nearly all employees perform sandblasting starting from their apprenticeship period. The fact that the age of diagnosis for dental technicians was younger than the ceramic workers seems to be related to them starting work in earlier ages as well as them performing sandblasting. When inspected according to their to tal exposure time, the decrease of minimum total exposure time to 2 years at ceramic workers, sandblasters, miners and dental technicians is an indication of serious dust exposure in workplaces at various sectors. The fact that sandblasting is still being used in various manufacturing areas in spite of its pneumoconiosis risk is disturbing in terms of employee health. 
Pneumoconiosis in different sectors and their differences in Turkey

Table 4. The comparison of the pulmonary function test results according to the profusion degree in smokers and non-smokers

\begin{tabular}{|c|c|c|c|c|c|c|}
\hline & \multicolumn{3}{|c|}{ Smokers $(n=50)$} & \multicolumn{3}{|c|}{ Non-smokers $(n=11)$} \\
\hline & $\begin{array}{c}\text { Profusion } 1 \\
(0 / 1,1 / 0,1 / 1,1 / 2)\end{array}$ & $\begin{array}{c}\text { Profusion } 2 \\
(2 / 1,2 / 2,2 / 3)\end{array}$ & $\begin{array}{c}\text { Profusion } 3 \\
(3 / 1,3 / 2,3 / 3,3 /+)\end{array}$ & $\begin{array}{c}\text { Profusion 1 } \\
(0 / 1,1 / 0,1 / 1,1 / 2)\end{array}$ & $\begin{array}{c}\text { Profusion } 2 \\
(2 / 1,2 / 2,2 / 3)\end{array}$ & $\begin{array}{c}\text { Profusion } 3 \\
(3 / 1,3 / 2,3 / 3,3 /+)\end{array}$ \\
\hline $\mathrm{FEV}_{1}$ & $87.4 \pm 16.4(52-113)$ & $87.0 \pm 17.6(67-107)$ & $68.6 \pm 23.0(26-87)$ & $83 \pm 17.3(68-102)$ & $76.5 \pm 19.6(40-93)$ & $88.5 \pm 6.3(84-93)$ \\
\hline FVC & $91.2 \pm 14.2(62-114)$ & $89.6 \pm 17.6(68-105)$ & $73.0 \pm 20.2(35-93)$ & $85 \pm 15.1(73-102)$ & $83 \pm 8.5(69-93)$ & $99.5 \pm 7.5(94-105)$ \\
\hline $\mathrm{FEV}_{1} / \mathrm{FVC}$ & $78.4 \pm 7.0(59-87)$ & $80.4 \pm 4.1(74-84)$ & $73.6 \pm 8.3(61-86)$ & $81 \pm 3.0(78-84)$ & $75.1 \pm 13.9(48-85)$ & $75.0 \pm 12.7(66-84)$ \\
\hline PEF & $91.4 \pm 22.9(53-128)$ & $83.0 \pm 15.0(64-98)$ & $73.8 \pm 24.3(37-106)$ & $81.6 \pm 12.5(70-95)$ & $85.8 \pm 29.7(34-124)$ & $89.5 \pm 10.6(82-97)$ \\
\hline
\end{tabular}

Table 5. The comparison of the pulmonary function test results according to the existence of big opacities in smokers and non-smokers

\begin{tabular}{|lccccc|} 
& \multicolumn{2}{c}{ Smokers $(\mathrm{n}=50)$} & & \multicolumn{2}{c}{ Non-smokers $(\mathrm{n}=11)$} \\
\cline { 2 - 3 } \cline { 5 - 6 } & Presence of largeopacities & Absence of largeopacities & & Presence of largeopacities & Absence of largeopacities \\
\hline $\mathrm{FEV}_{1}$ & $58.5 \pm 22.6(26-84)$ & $87.9 \pm 15.2(52-113)$ & & $76.5 \pm 19.6(40-93)$ & $84.8 \pm 10.6(68-102)$ \\
$\mathrm{FVC}$ & $67.8 \pm 20.1(35-88)$ & $90.9 \pm 14.3(62-114)$ & & $82.3 \pm 12.5(69-94)$ & $88.1 \pm 11.3(73-105)$ \\
$\mathrm{FEV}{ }_{1} / \mathrm{FVC}$ & $67.1 \pm 7.9(59-80)$ & $79.3 \pm 5.8(66-87)$ & & $68.6 \pm 18.5(48-84)$ & $79.7 \pm 6.1(66-85)$ \\
$\mathrm{PEF}$ & $61.0 \pm 23.2(37-93)$ & $91.4 \pm 20.7(53-128)$ & & $68.6 \pm 30.2(34-90)$ & $91.6 \pm 16.6(70-124)$ \\
\hline \multicolumn{2}{l}{ One-way } & & & & \\
\hline
\end{tabular}

Even though the sociodemographic properties change according to the population the study has been conducted, the cases with pneumoconiosis are usually from the younger age groups $(15,16)$. Substantial factors that come into mind are starting employment in an early age such as in dental technicians, and the fact that unskilled workers have a higher chance in finding jobs at fields that do not require any craftsmanship, and the high turnover rate at workplaces (16-19). According to the Republic of Turkey Turkish Statistical Institute (TÜIK) data, the unemployment ratio in 2015 was 10.3\% (20). This may also be one of the reasons for the younger population who have difficulty in finding jobs, to have a higher possibility of becoming unskilled workers. Another factor that may have affected the work-disease indicators is that because our outpatient clinic is a specialisation centre, the cases may have been directly referred from the risk areas to our outpatient clinic.

It is known that the exposure to either pure crystalline silica on its own or to a mixture of nonfibrous silicates and crystalline silica usually causes nodular form fibrosis mainly in the upper lobes $(21,22)$. In accordance with this information, the most common pneumoconiosis related radiological findings that we detected were small opacities with " $p$ " properties.

However the existence of " $r$ and $q$ " opacities in more than approximately $10 \%$ of the cases and $\geq 2$ profusion in $34.4 \%$ of the cases, and the detection of parenchymal irregularity in $40 \%$ of the cases, and big opacities in $15 \%$ of the cases suggests the probability of severely late diagnosis.

In a study evaluating the radiological findings of 50 denim sandblasters, it has been reported that the most common finding was nodules and that the nodules were accompanied with lymphadenopathy in half of the cases (23). The most common HRCT finding in our study was micro-nodules and lymphadenopathy $(72.1 \%$ and $42.6 \%$ respectively). Despite its technical limitations the HRCT has contributed in confirming the diagnosis of the doubtful cases and the evaluation of the mediastinal lymph nodes.

In our study, micro-nodules were found to be distinctive especially at ceramic workers and sandblasters $(p=0.004)$. Lymphadenopathy was identified significantly much more in dental technicians $(p=0.007)$. During dental prosthesis production, the risk of exposure not only to silica crystals but also to different chemicals such as methacrylate, and various metals such as beryllium, nickel, and cobalt comes into the question $(24,25)$. It has been considered that the mediastinal lymphadenopathy could be related to conditions such as hypersensitivity pneumonitis caused by 
agents apart from silica, or chronic beryllium disease, however additional mineralogical or immunohistopatological assessments could not be performed.

In our study, it has been observed that in cases who smoked, the more their radiological pneumoconiosis findings increased, the more their functional impairment significantly increased. This result reveals once more the significance of preventing smoking in order to protect the employees' health. On the other hand, the fact that especially the big opacities had been accompanied with significant functional impairment and a problem like weight loss is noticeable. This may be due to a systematic inflammation resulting from pneumoconiosis (26).

Even though $31 \%$ of the cases in our study had no complaints, inspiratory symptoms were the primary ones among the symptoms which were indicated. Although the existence of symptoms and the risk of functional impairment have been found to be higher in cases with complicated pneumoconiosis, the high incidence of smoking makes it impossible to discuss the exact relationship between the symptoms and pneumoconiosis.

The cases which we diagnosed with pneumoconiosis worked as ceramic workers, dental technicians, sandblasting workers, welders, marble cutters and casters. The diagnosis age of the dental technicians were significantly younger than the ceramic workers $(p=0.003 ; 34$ and 41 years old respectively). We saw that this situation resulted from the fact that dental technicians started working at an earlier age than the ceramic workers $(p<0.001 ; 17$ and 23 years old respectively). When the total exposure times were compared, it was seen that the cases which did sandblasting had developed the disease in spite of their shorter total exposure times. The exposure times of the sandblasters were significantly shorter, especially than the ceramic workers $(p=0.002 ; 48$ and 194 months respectively). This situation may be explained by the differences between the contents and the concentration of the dust which the workers from various sectors have been exposed to $(8,22,26)$.

Our study is the first study in our country to present the cases diagnosed with pneumoconiosis according to the differences among their occupations. The major limitations of our study are that it does not cover all the employees in a workplace but only the cases referred to our outpatient clinic with the suspicion or pre-diagnosis of pneumoconiosis; that the study does not include the workplace environmental analyses data; that the exposure has been evaluated according to the cases' anamnesis, and that additional mineralogical or immunohistopathological tissue examinations for differential diagnosis have not been conducted.

\section{CONCLUSION}

Pneumoconiosis still exists in Turkey. Even a short exposure time as 2 years can cause pneumoconiosis. Workers in different sectors had different functional, radiological properties and smoking can affect the diseases' course. There are serious limitations related to the surveillance of both the workplace environment and the employees' health in Turkey. Without institutional preventive measures, personal protection and surveillance examinations, occupational hazards will continue to cause premature deaths. Pneumoconiosis in different sectors is a prototype of uncontrolled industry in the developing world.

\section{ACKNOWLEDGEMENTS}

NSA is the guarantor of the content of this manuscript, had full access to all of the data in the study and takes responsibility for the integrity of the data and the accuracy of the data analysis. NSA, ACB and AHC contributed substantially to the study design, data analysis and interpretation, and the writing of the manuscript. There are no conflicts of interests and no kind of funds or grants were used for this study.

\section{REFERENCES}

1. ILO "Guidelines for the use of ILO international classification of radiographs of pneumoconiosis". International Labour Office, Geneva 1980

2. Fingerhut $M$, Nelson DI, Driscoll $T$, Goncha-Barrientos $M$, Steeland K, Punnet $L$, et al. The contribution of occupational risks to the global burden of disease: summary and next steps. Med Lav 2006;97:313-21.

3. Morgan WKC, Burgess DB, Jacobsen G, O'Brien RJ, Pendergrass $E P$, Reger $R B$, et al. The prevalence of coalworkers' pneumoconiosis in US coalminers. Arch Environ Health 1973;27:221-6.

4. Takala J. Introductory Report of the International Labour Office (ILO). Geneva Occupational Safety and Health Branch, International Labour Office (ILO) 1999.

5. Sosyal Güvenlik Kurumu Istatistiksel Yıllıkları. Available from: http://www.sgk.gov.tr/wps/portal/tr/kurumsal/ istatistikler/sgk_istatistik_yilliklari 
6. Sevinç C, Cimrin AH, Manisalı M, Yalcın E, Alkan Y. Sandblasting under uncontrolled and primitive conditionals in Turkey. J Occup Health 2003;45:66-9.

7. Cömert MA, Yılmaz H, Gebeşoğlu BE, Tutkun E, Keskinkılıç $B$, Soydal T. Kaynak işçilerinde pnömokonyoz gelişimi yönünden risk faktörlerinin değerlendirilmesi. Ankara Med J 2014;14:11-4.

8. Şakar A, Kaya E, Çelik P, Gencer N, Temel O, Yaman N, et al. Evaluation of silicosis in ceramic workers. TuberkToraks 2005;53:148-55.

9. Doğan DÖ, Özdemir AK, Polat NT, Dal U, Gümüş C, Akkurt I. Prevalance of respiratory abnormalities and pneumoconiosis in dental laboratory technicians. Tuberk Toraks 2010;58:13541.

10. Karadağ KÖ, Akkurt i, Önal B, Altınors M, Bilir N, Ersoy N, et al. Silicosis and respiratory findings in quarry workers. Tuberk Toraks 2001;49:73-80.

11. Çımrın A, Erdut Z. General aspects of pneumoconiosis in Turkey. Indian J Occup Environ Med 2007; 11:50-5.

12. Ödev K. Toraks Radyolojisi Kitabı. Nobel Tıp Kitabevi 2005:28.

13. American Thoracic Society. Standardization of spirometry: 1994 update. Am J Respir Crit Care Med 1995;152:110736.

14. Çımrın A, Tertemiz KC, Alpaydın AÖ. Silikozis oluşumunda yeni bir meslek: Olgu sunumu (poster sunumu). Türk Toraks Derneği 17. Yıllık Kongresi Program ve Bildiri Kitabı; 2014 Antalya.

15. Numanoğlu N, Gönüllü U, Özdemir Ö, Savaş I, Şimşek C, Atakurt $Y$, et al. Pulmonary findings and pneumoconiosis in 12.300 coalminers. Doga-Tr J of MedicalSciences 1992;19: 227-38.

16. Öztürk A, Çımrın AH, Tür $M$, Güven R. Kuartz ve feldspat değirmenlerinde çalışanlarda silikozis sıklığı ve silikoz ile ilişkili faktörler. Tuberk Toraks 2012;60:224-9.
17. Akgün M, Araz O, Akkurt I, Eroğlu A, Alper F, Sağlam F, et al. An epidemic of silicosis among former denim sandblasters Eur Respir J 2008;32:1295-303.

18. Akgün M, Araz O, Uçar EY, Karaman A, Alper F, Görgüner $M$, et al. Silicosis appears inevitable among former denim sandblasters: a 4-year follow-up study. Chest 2015;148:574-6.

19. Boratav K. istanbul ve Anadolu'dan sınıf profilleri toplumsal sınıflar: Ampirik ölçütler ve genel çerçeve; istanbul: Numune Matbaacılık, 1995:1-8.

20. Türkiye istatistik Kurumu (TÜiK) 2015 verileri. Available from: http://www.tuik.gov.tr/PreTablo.do?alt_id=1007.

21. Honma K, Abraham JL, Chiyotani K, De Vuyst P, Dumortier P, Gibbs AR, et al. Proposed criteria for mixed-dust pneumoconiosis: definition, descriptions, and guidelines for pathologic diagnosis and clinical correlation. Hum Pathol 2004;35:1515-23.

22. Diseases associated with exposure to silica and nonfibrous silicate minerals. Silicosis and Silicate Disease Committee. Arch Pathol Lab Med 1988;112:673-720.

23. Alper $F$, Akgün M, Onbas $O$, Araz O. CT findings in silicosis due to denim sandblasting. Eur Radiol 2008;18:2739-44.

24. Scherpereel A, Tillie-Leblond I, Pommier de Santi P, Tonnel AB. Exposure to methyl methacylate. Allergy 2004;59:890-2.

25. Çömlekoğlu ME, Dündar M, Güngör MA, Aladağ A, Artunç C. Allergy in dentistry: casting alloys, polymers and ceramics. EÜ Dişhek Fak Derg 2008;29:81-92.

26. Leung CC, Yu IT, Chen W. Silicosis. Lancet 2012;379:2008. 